\title{
スイバの染色体形態はどのように多様化してきたのか
}

\author{
柴田 洋 \\ 愛媛大学 理学部 \\ (テ790-8577 愛媛県松山市文京町 2-5)
}

\section{How did the shape of Rumex acetosa L. chromosomes diversify?}

\author{
Fukashi Shibata \\ Faculty of Science, Ehime University, Matsuyama 790-8577, Japan
}

要旨: 高等植物のゲノムは大量の反復配列によって構成されている。これらの反復配列は、個々の ゲノムが進化する過程でどのような役割を果たしてきたのか、スイバ（Rumex acetosa）の反復配 列の解析から考察してみた。スイバは異質染色質化した Y 染色体をもち、常染色体とY染色体に多 型がみられる。スイバの常染色体に見られる多型は余剩異質染色質分節の付加によってもたらされ ており、その大きさは余剩異質染色質分節を構成する反復配列のコピー数の増減によって変化して いた。 $\mathrm{Y}$ 染色体は性染色体の分化後に、2 種類の異なる反復配列が染色体全体に蓄積することによ って特殊化してきたことが明らかになった。Y 染色体の形態にみられる多型は、反復配列の増減を 伴わない染色体の構造変化によってもたらされていた。

Summary: There are many repetitive sequences in the genomes of higher plants. The significance of repetitive sequences and their role in evolution are not clear. I analyzed tandemly arranged repetitive sequences in Rumex acetosa to obtain clues to answer these questions. In $R$. acetosa, the Y chromosomes are highly heterochromatic and chromosome shape polymorphisms are observed in autosomes and $\mathrm{Y}$ chromosomes. I discuss the role of repetitive sequences in the evolution of sex chromosomes and in morphological polymorphism of chromosomes. The morphological changes in autosomes result from an increase or decrease in the number of tandemly arranged repetitive sequences. In the sex chromosomes, specialization of the $\mathrm{Y}$ chromosome is promoted by the accumulation of two tandemly arranged repetitive sequences in the process of sex chromosome evolution. The morphological changes in the $\mathrm{Y}$ chromosomes result from a rearrangement of the chromosome arms, and do not involve a change in the number of repetitive sequences.

Key word: Rumex acetosa, repetitive sequence, evolution, intraspecific karyotype variation 
1.はじめに

全ての生物は、種固有の特徵を持ったゲノムを持っている。各ゲノムの形態的特徴は、染色体の数、 大きさ、動原体位置、二次狭窄、各種のバンド等としてあらわれる。特に高等植物では染色体形態 が多様であり、種間におけるゲノムサイズの違いも大きい。ゲノム固有の染色体の特徴がどのよう に進化して来たのか、興味が持たれる点である。植物では、ゲノム DNA 中に占める反復配列の割 合が非常に高く、種によっては 90\%以上に達するといった報告もある（Flavell et al. 1974）。反復 配列は、種や属といった単位で塩基配列の共通性、多様性、量の多様性が多く報告されており、反 復配列の分布はゲノムに固有の染色体の形態学的特徵をもたらすのに重要な役割を持っていると考 えられる。ゲノム中に存在する反復配列は、その分布状態からゲノム中に散在して存在する散在型 反復配列と特定部位に反復単位が緃列している縦列型反復配列に分けられる。縦列型反復配列は染 色体上で異質染色質を形成していることが多く、個々の染色体上での異質染色質の増減が核型に多 型をもたらすことが多い（Marks and Schweizer, 1974, Deumling and Greilhuber 1982, Ruiz Rejon and Ruiz Rejon 1985, Kurita and Kuroki 1971ab, 1975, Kuroki 1987, Wilby and Parker 1988)。雌雄異株の被子植物であるスイバ（Rumex acetosa）は明瞭な性染色体を持つことで知ら れ、雌株は $\mathrm{XX}$ 、雄株は $\mathrm{XY}_{1} \mathrm{Y}_{2}$ の性染色体を持っている（Kihara and Ono, 1923）(図 1,2)。スイ バでは 2 本のY染色体と 3 対の常染色体の短腕端部に異質染色質が見られる(Yonezawa et al. 1978, Kuroki 1984,1987）（図 1,2）。スイバの常染色体の端腕端部に見られる異質染色質には多型が見ら れ、この異質染色質部を構成する塩基配列をクローニングし、染色体の多型とのかかわりを解明し ている（Shibata et al. 2000a）。高等植物では、雌雄異株である種は全体の数\%程度といわれてお り明瞭な性染色体が分化している種はさらに少ない。スイバは染色体全体が異質染色質化した 2 本 の Y 染色体をもつという特異な性染色体の構成を持つことから性の進化に伴いどのような変化が染 色体に起こったのか興味がもたれる。スイバの染色体に見れれる染色体多型の解説と性染色体の進 化について考察してみたい。

図 1 DAPI 染色したスイバ雄株の中期染色体像。 矢頭は常染色体の余剩異質染色質分節を示す。この 個体は 3 本の常染色体に余剩異質染色質分節がみ られる。

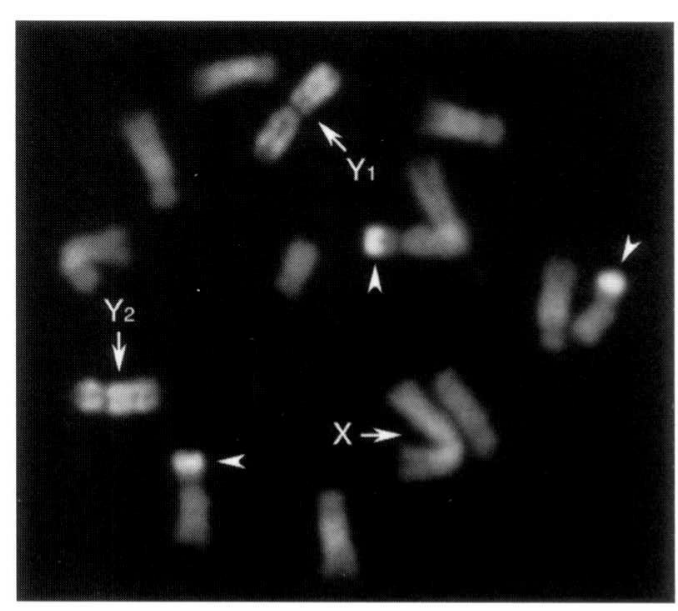

図 2 スイバの雌雄の核型の模式図。雄株は $2 n=X_{1} Y_{2}+12$ 、雌株は $2 n=X X+12$ の核型をもつ。 黒塗りの部分は異質染色質を表している。 $Y_{1} 、 Y_{2}$ 染色体は染色体全体が異質染色質化している。常染 色体では最高で $2 、 4 、 6$ 番染色体の端腕端部に異質 染色質が見られる。
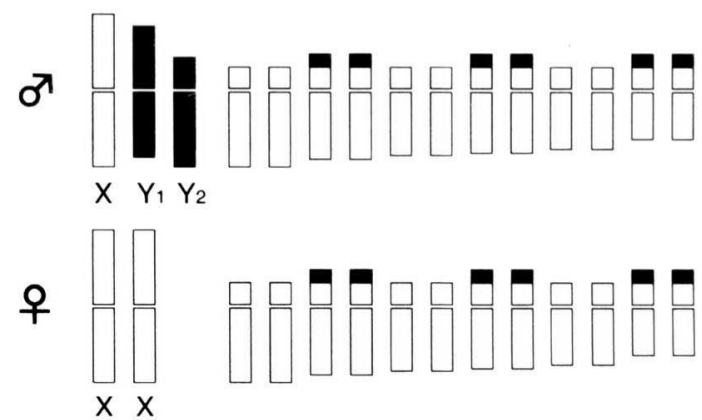


\section{2. 常染色体に見らる染色体形態の多型}

スイバには、余剩異質染色質分節による種内の核型多型が観察される。余剩異質染色質分節は C. バンド、DAPI バンド陽性部として 3 対の常染色体の短腕端部に出現する（Kurita and Kuroki 1971a，1975, Kuroki 1987, Wilby and Parker 1988）（図 1,2，3）。余剩異質染色質分節をもつ常染 色体の数は個体毎に異なり、それぞれの余剩異質染色質分節の大きさにも変異が見られる。これら の染色体の組み合わせによりスイバでは多様な核型多型が観察される。余剩異質染色質分節をもつ 個体に特異的な $730 \mathrm{bp}$ の縦列型の反復配列（RAE730）が得られており、in situハイブリダイゼー ション（ISH）による解析から RAE730は常染色体の余剩異質染色質分節に局在することが確かめ られた（Shibata et al. 2000a)。常染色体の余剩異質染色質分節に見られる数的、量的な変異と $R A E 730$ のコピー数の多少に正の相関が見られ常染色体に観察される余剩異質染色質分節による核 型多型が RAE730 のコピー数の変異によってもたらされていると推定できた（Shibata et al. 2000a)。どのようなメカニズムで各染色体上の RAE730 配列のコピー数は変化するのたろうか。 まずは減数分裂時の不等交叉によって相同染色体間で RAE730 のコピー数の変動が起きる可能性 が考えられる。また、RAE730配列は間期核上でクロモセンターを形成していることが知られてい る。分裂直後の核では $R A E 730$ が形成するクロモセンターの数は各個体の持つ常染色体上の余剩異 質染色質分節の数に対応する。そして、間期核上のクロモセンターは時間とともに融合し、大きな クロモセンターを形成することが知られている（Kuroki and Kurita 1971, Kurita and Kuroki 1971a）（図 3)。この場合融合したクロモセンター内では非相同な染色体のもつRAE730の反復部 分が組換えを起こす可能性がある。体細胞での観察例と同じクロモセンターの融合が精母細胞内で 起きる可能性は十分に考えられる。しかし、個々の常染色体の余剩異質染色質分節の大きさに個体 内での変化は見られないことから、融合したクロモセンター内での RAE730の組換えが起きる頻度 は高くないと考えている。

図 3 A：常染色体の余剩異質染色質分節 の多型を示す模式図。模式図に示した異質 染色質分節の多型が $2,4,6$ 番染色体それ それに観察される。B: 余剩異質染色質分 節に特異的な塩基配列 RAE730 をプロー ブとしたスイバの間期核の ISH 像。この 写真では間期核上に 2.4 個のシグナルが 観察される。シグナルの数の違いはクロモ
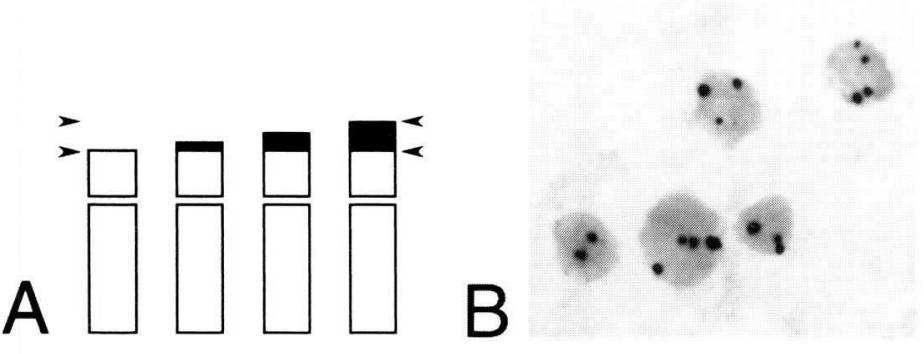
センターの融合を示している。

\section{3. 性染色体と異質染色質}

スイバは明瞭な性染色体をもつ。雄株は 1 本の X 染色体と 2 本の $\mathrm{Y}$ 染色体 $\left(\mathrm{Y}_{1}, \mathrm{Y}_{2}\right)$ をもち、雌 株は 2 本の X 染色体をもつ。両 Y 染色体は染色体全域が異質染色質化しており、C-バンド、DAPI バンド陽性の複数のバンドが観察される（Yonezawa et al. 1978, Kuroki 1984, 1987)。スイバの Y 染色体では、マイクロダイセクションによって単離した Y 染色体の DOP-PCR 産物をプローブとし たクロモソームペインティングを行うことができる (Shibata et al. 1999)。ペインティングシグナ 
ルは両 Y 染色体の染色体全体に観察される（図 4)。シグナルは両 Y 染色体上の DAPI バンドに一 致していたことから、両 $\mathrm{Y}$ 染色体は $\mathrm{Y}$ 染色体に特徵的な塩基配列を含み、それらは DAPI バンドを 構成していることが明らかになった。Y 染色体の分化は、染色体中に $\mathrm{Y}$ 染色体に特徵的な反復配列 を蓄積しながら特殊化することによって進んできたと推測できた。Y 染色体上に蓄積している縦列 型の反復配列として、Y 染色体の DOP-PCR 産物から 930bp の反復単位をもつ Y 染色体特異的な 縦列型反復配列である RAYSI が得られている（Shibata et al. 1999）。Y 染色体と常染色体に分布 するRAE180も単離されている（Shibata et al. 2000b)。RAYS とRAE180は $\mathrm{Y}_{1} 、 \mathrm{Y}_{2}$ 染色体上で 両染色体に特有のパターンを持って分布している（図 5)。この結果から、両 Y 染色体が大量の縦列 型反復配列を蓄積していることが明らかになった。また RAE180 は Y 染色体以外に常染色体の 1 番と 4 番染色体にも分布している。同じ塩基配列が $\mathrm{Y}$ 染色体上と常染色体上に分布するという事実 から、性染色体が分化した後で Y 染色体と常染色体の間で転座等による塩基配列の移動があったと 推測された。

図 4 スイバ雄株の染色体のペインティングシグナ ル。2 本の $\mathrm{Y}$ 染色体に強いシグナルが見られる。矢 印は $Y_{1}$ 染色体、矢頭は $Y_{2}$ 染色体を示す。

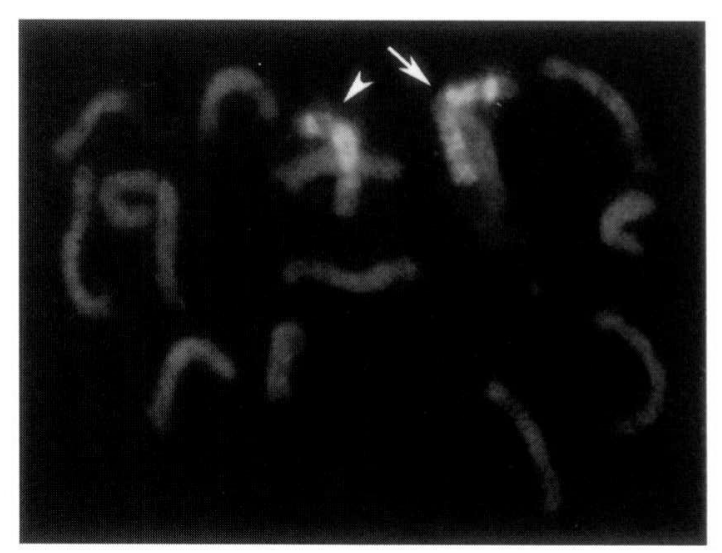

図 5 スイバ $\mathrm{Y}_{1} 、 \mathrm{Y}_{2}$ 染色体上の $R A Y S I$ と RAE180のシグナル。両 $\mathrm{Y}$ 染色体上で RAYSI と RAE180 は特有のシグナルパターンを示し 染色体、染色体腕の同定が可能で ある。

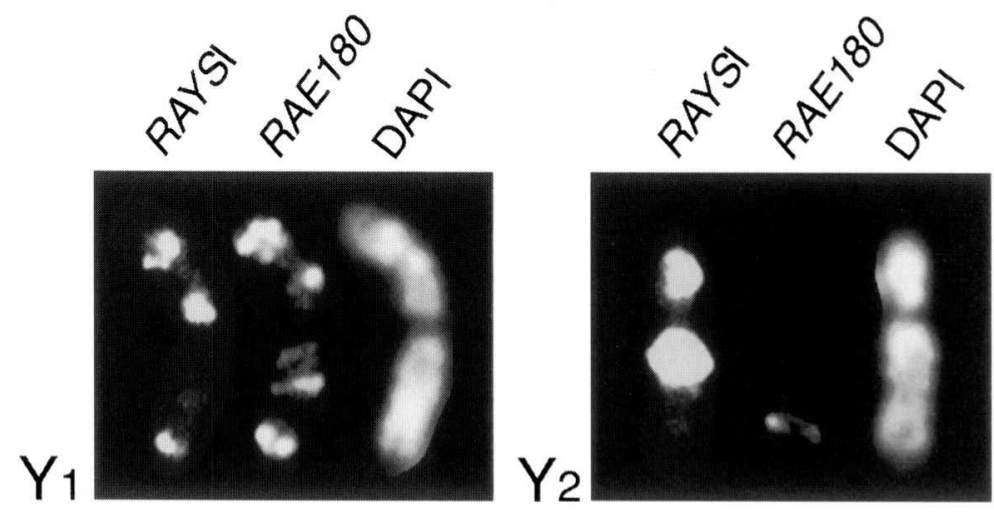

\section{4. 性染色体に見らる染色体型の多型}

スイバの $\mathrm{Y}$ 染色体は、染色体長の長い方が $\mathrm{Y}_{1}$ 、短い方は $\mathrm{Y}_{2}$ と呼ばれる。しかし、両 $\mathrm{Y}$ 染色体の 染色体型には多型がみられるため $\mathrm{Y}_{1} 、 \mathrm{Y}_{2}$ 染色体の質的な違いを表してはいなかった。Y 染色体上に は、2 種類の反復配列 $R A Y S$ と $R A 180$ がそれぞれ特有のパターンをもって分布しているため、両 反復配列をプローブとした FISH のシグナルをもとに染色体と染色体腕の同定が可能であった。 $R A E 180$ と RAYSI をプローブとした FISH によって Y 染色体の形態多型の解析を試みた (Shibata 
et al. 2000b)。3グループの染色体型の異なる Y 染色体の FISH シグナルのパターンを比較したと ころ、異なった Y 染色体グループ間の類縁関係が明かになった。3グループに分類された Y 染色体 の組み合わせのうちグループ II と III はグループ I の Y 染色体の $\mathrm{Y}_{1} 、 \mathrm{Y}_{2}$ 染色体から派生したもの であることが明らかになった。グループ II の両 Y 染色体はグループ I の $\mathrm{Y}_{1} 、 \mathrm{Y}_{2}$ 染色体相互転座に よって形成されており、グループ III の $\mathrm{Y}_{1}$ 染色体はグループ I の $\mathrm{Y}_{1}$ 染色体の挟動原体逆位によっ て形成されていた（図 6)。いずれの Y 染色体もグループ I の Y 染色体から派生したものであった ので、スイバの Y 染色体はグループ I が基本となっていることがわかる。また、いずれの Y 染色体 グループでも、反復配列の増減によるFISHパターンの変化は見られず、反復配列の FISHパター ンは保存されていると考えられた。このことから、Y染色体の多型はグループ I の現在の Y 染色体 の形態が確立された後に、独立に生じた変異だと考えられる。

図 6 多型を示すスイバの $\mathrm{Y}$ 染色体の 中期染色体像と模式図。グループ I, II, III それぞれ異なった $\mathrm{Y}_{1} 、 \mathrm{Y}_{2}$ 染色体の組 み合わせとなっている。模式図の各染 色体腕の模様はグループ I の両 Y 染色 体の各腕との対応を示す。

I
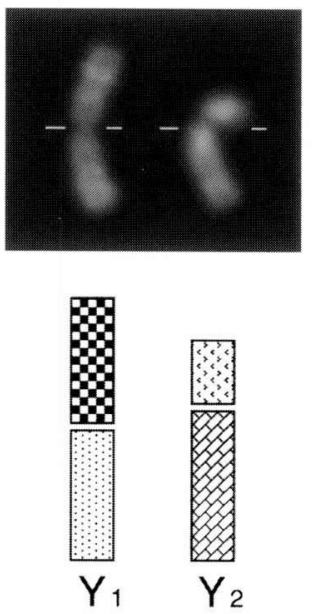

II
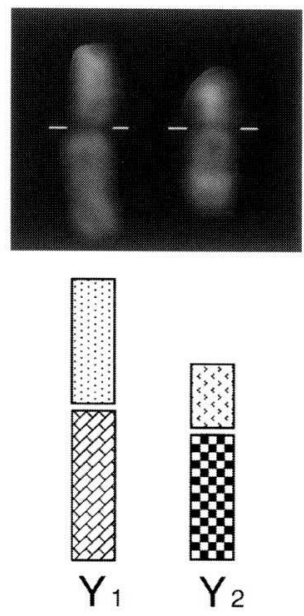

III
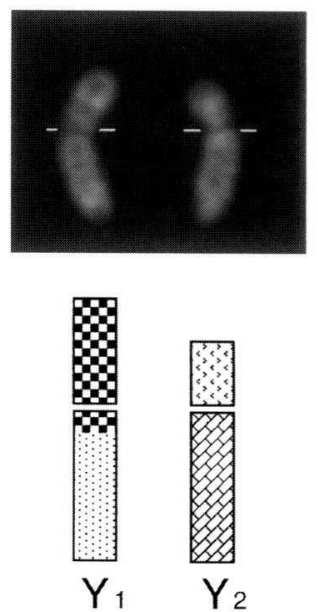

5. 性染色体の進化

高等植物において明瞭な性染色体を持つ種は少ない。植物のもつ性染色体の形態的特徵、性決定 に関する役割等は様々であり、詳しくは植物の性に関する総説を参考にしていただきたい（黒木 1975, 松永・黒岩 1996, 曾根ら 1996, Matsunaga and Kawano 2001)。スイバにおいては、Y染 色体の異質染色質化が進んでいることからY染色体の異質染色質化がどのように進んできたのかに 注目して性染色体の進化を考えてみたい。図7にスイバにおける性染色体の進化を模式図にして表 してみた。Y 染色体には RAE180 と RAYSI が大量に分布している。 $\mathrm{X}$ 染色体にはこのような反復 配列の蓄積は観察されないことから、性染色体が分化し XY 染色体間での組換が抑制された後に、 $\mathrm{Y}$ 染色体への縱列型反復配列の蓄積が起きたと考えられる。スイバの 2 本の Y 染色体はどのように 形成されてきたのだろう。スイバの減数分裂における性染色体の対合では $\mathrm{X}$ 染色体の両端部に $\mathrm{Y}_{1}$, $\mathrm{Y}_{2}$ 染色体が別々に端部で結合し三連染色体と呼ばれる形態をとることが知られている。Y染色体ど うしの対合は見られないことから Y 染色体間には相同な部分が存在しないことがうかがえる。 FISH 解析においても両 Y 染色体のシグナルパターンには相同性は見られない。しかし、両 Y 染色 体は X 染色体と同じ祖先染色体から分化したと考元られ、両 $\mathrm{Y}$ 染色体上には共通の反復配列である $R A Y S I ， R A E 180$ が分布している。共通の反復配列が分布するという側面から考えた場合両 Y 染色 体の関係は近いといえる。 $Y_{1}, Y_{2}$ 染色体が形成されたのは、祖先型 $\mathrm{Y}$ 染色体が形成され、祖先型 $\mathrm{Y}$ 
染色体上に反復配列 RAYSI と RAE180が蓄積した後であると考えられる。

スイバにおける Y 染色体の役割はどうなっているのであろう。Ono（1935）は倍数体の性染色体 の構成と性表現を観察し、Y 染色体には性決定能がなく、スイバの性は X 染色体と常染色体の比率 で決定されるとしている。RAE180が Y 染色体と常染色体に共通して分布することから、Y染色体 と常染色体の間では塩基配列の移娌が起きたと考えられ、その際、Y 染色体上に存在し、性決定に 関与していたなんらかの道伝子が常染色体上へ移動した可能性がある。また、Y 染色体が性決定に 関与しないことを考虑すると、逢伝子を失った Y 染色体に反復配列が大量に蓄積していった理由が 理解できる。しかし、Y 染色体は本当に機能を失った染色体なのであろうか。FISH 解析で明らか になったように、Y 染色体上の反復配列の分布バターンは保存されている。染色体が機能を失った 場合、染色体に蓄積される変異が多くなり、反復配列の分布パターンにも多くの変異が起きると考 えられる。現在のスイバの Y 染色体の構造は、比較的保存されていると考えられることから、Y 染 色体には現在の槽造を維持するような淘汰圧がかかっていると推測される。スイバのY 染色体の役 割については今後再考されるべき問題が含まれていると考えている。

図 7 スイバの染色体進化 を表した模式図。A:ある染 色体対が性染色体に分化し 染色体間の組换えが抑制さ れた。B: $\mathrm{Y}$ 染色体に RAYSI やRAE180か蓄糟して異質 染色筫化が進んた。C: Y 染 色体と常染色体間で転座等 による塩基配列の移動が起 き RAE180か常染色体上に も分布するようになった。 D: $\mathrm{Y}$ 染色体が 2 本の $\mathrm{Y}_{1} 、 \mathrm{Y}_{2}$ 染色体に分化した。模式図 中の黒㳂りの部分は縦列型 のの反復配列の蓄積を示め す。また、模式困に示した 各染色体の形態は現在のス イバの核型を表すものでは ない。
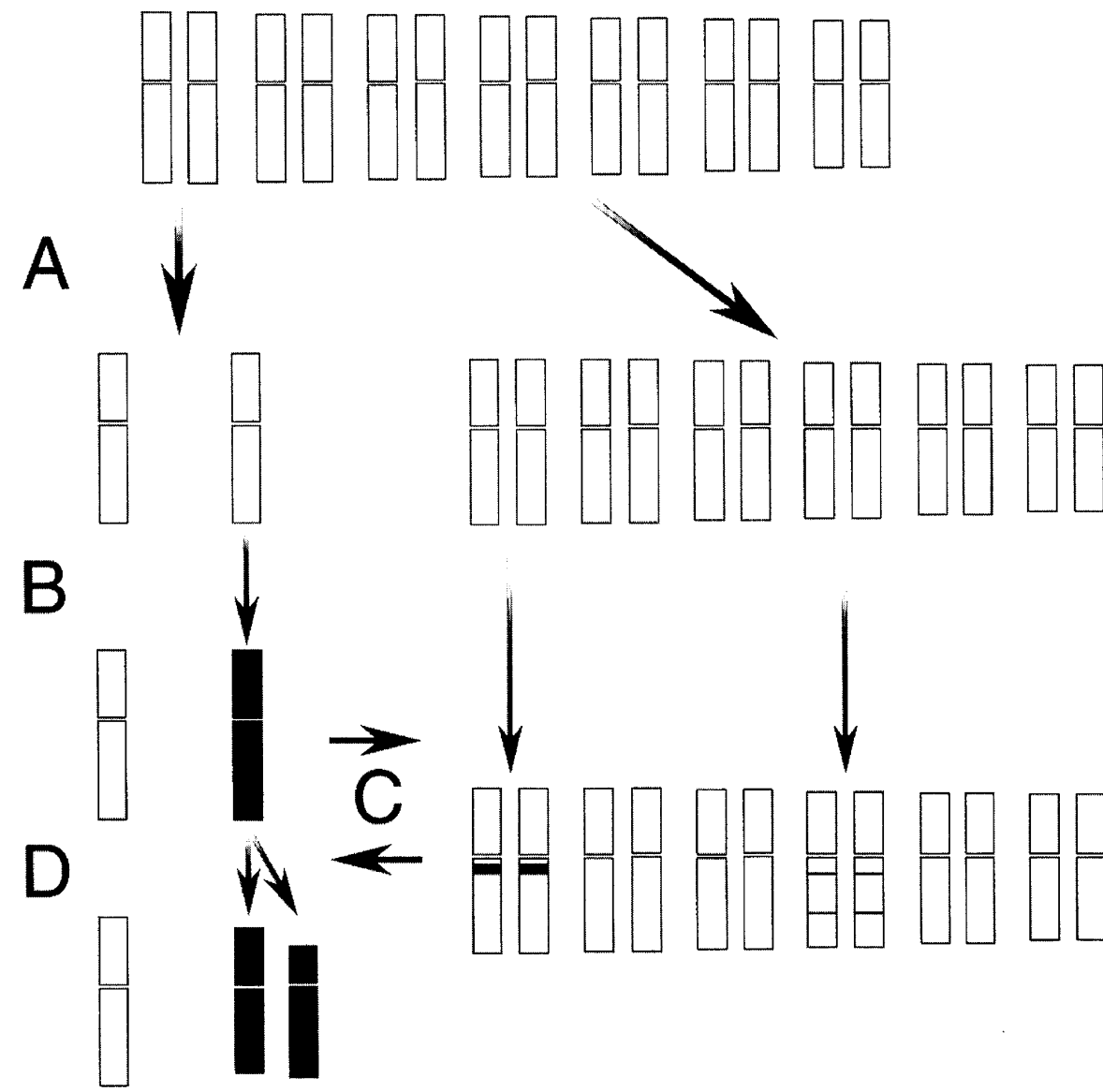

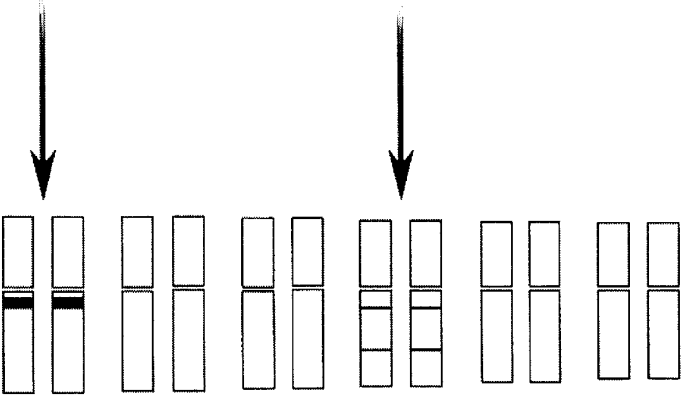

6. おわりに

本総説で解説した塩基配列はいずれも縦列型の反復配列である。スイバでは縦列型の反復配列が常 染色体の染色体多型と $\mathrm{Y}$ 染色体の特殊化に関与していた。一般に、異質染色質の分布パターンは個々 
の染色体に固有の特徴をもたらし、核型分析のためのマーカーとして有用である。スイバにおいて もその起源、進化を考えることはゲノムの進化を考える上で有意義であった。今後、さらに高等植 物におけるゲノム進化に関する理解を深めるには、散在型の反復配列とゲノム進化の関係を考察す ることが必要であろう。

\section{参考文献}

Deumling B and Greilhuber J (1982) Characterization of heterochromatin in different species of the Scilla siberica group (Liliaceae) by in situ hybridization of satellite DNAs and fluorochrome banding. Chromosoma 84: 535-555.

Flavell RB, Bennett MD, Smith JB and Smith DB (1974) Genome size and proportion of repeated nucleotide sequence DNA in plants. Biochem. Genet 12:257-269

Kihara H and Ono T (1923) Cytological studies on Rumex L., I. Chromosomes of Rumex acetosa L. Bot. Mag. Tokyo 37: 84-90

Kurita M and Kuroki Y (1971a) Chromocenters in Rumex acetosa nucleus. Bot. Mag. Tokyo 84: 18-23

Kurita M and Kuroki Y (1971b) Morphological variation in certain autosomes of Rumex acetosa. Bot. Mag. Tokyo 84: 411-415.

Kurita M and Kuroki Y (1975) Heterochromatic segment of Rumex acetosa autosomes. Cytologia 40: 237-242.

黒木西三 (1975) 性染色体 遭伝 29 (8): 18-24

Kuroki Y (1984) Fluorescence patterns of Rumex acetosa chromosomes. Chromosome Information Service 37: 29-31

Kuroki.Y (1987) Karyotype variation and heterochromatin in Rumex acetosa. Nishiki Printed Co., Ltd., Shoko Center, Hiroshima 730, Japan. pp. 227-230.

Kuroki Y and Kurita M (1971) Chromocenter number in Rumex acetosa L. Jpn. J. Genet. 46: 295-300

Marks GE and Schweizer D (1974) Giemsa Banding: karyotype difference in some species of Anemone and Hepatica nobilis. Chromosoma 44: 405-416.

松永幸大・黒岩常祥 (1996) 植物の性染色体 遺伝 50 (6): 27-32

Matsunaga S and Kawano S (2001) Sex determination by sex chromosomes in dioecious plants. Plant biol. 3: 481-488

Ono T (1935) Chromosomen und Sexualität von Rumex acetosa. Sci. Rep. Tohoku Imp. Univ. IV, 10: $41-210$

Ruiz Rejón C and Ruiz Rejón M (1985) Chromosomal polymorphism for a heterochromatic supernumerary segment in a natural population of Tulipa australis Link. (Liliaceae). Can. J. Genet Cytol., 27: 633-638. 
Shibata F, Hizume M and Kuroki Y (1999) Chromosome painting of $Y$ chromosomes and isolation of a $\mathrm{Y}$ chromosome-specific repetitive sequence in the dioecious plant Rumex acetosa. Chromosoma 108: 266-270.

Shibata F, Hizume M and Kuroki Y (2000a) Molecular cytogenetic analysis of supernumerary heterochromatic segments in Rumex acetosa. Genome 43: 391-397

Shibata F, Hizume M and Kuroki Y (2000b) Differentiation and the polymorphic nature of the Y chromosomes revealed by repetitive sequences in the dioecious plant, Rumex acetosa. Chromosome Research 8: 229-236

曽根岳史・福澤秀哉・大山莞爾 (1996) 植物の性決定機構解明への道「植物のゲノムサイエンス」 監修 大山莞爾・飯田滋・島本功 pp67-75 秀潤社

Wilby AS and Parker JS (1988) The supernumerary segment systems of Rumex acetosa. Heredity 60: 109-117.

Yonezawa Y, Tanaka R and Kuroki Y (1978) C-banding treatment of sex chromosomes in Rumex acetosa L. Chromosome Information Service No.25: 31-32. 